Are all thy playthings snatched away?

Но низкой жаждой самовластья

Твоя душа была полна.

Ты думал: на вершину счастья

Взнесут пустые имена!

Где ж пурпур твой поблекший ныне?

Где мишура твоей гордыни:

Султаны, ленты, ордена?

Ребенок бедный! Жертва славы!

Скажи, где все твои забавы?

Майстер вірша, сміливий новатор ідей та перекладу В. Брюсов в перекладах своїх завжди допитливо шукав такі форми і поєднання слів, щоб швидше за все знайти відгук у читача, «поразить» його увагу, змусити запам'ятати «невольно и навсегда» [3, с. 457-458].

\title{
Література:
}

1. Беджанян К. Г. Подробно о переводах из Стивенсона. Научные труды. Вопросы филологии. Ереван, 2003. Выпуск № 1. С. 40-46.

2. Брюсов В. Я. Мастерство перевода. Сборник статей. М. 1959. C. $373-377$.

3. Брюсов В. Я. Собрание сочинений : в 7 т. М. : Худож. лит., 1973. T. $3.672 \mathrm{c}$.

4. Брюсов В. Я. Собрание сочинений : в 7 т. М. : Худож. лит., 1973. T. 7. $496 \mathrm{c}$.

5. Мур Т. Валерий Брюсов. Литературное наследство. М., 1986. T. 91. C. 39-40.

DOI https://doi.org/10.30525/978-9934-26-039-1-77

\section{ПРОБЛЕМИ ПЕРЕКЛАДУ МЕДИЧНИХ ТЕРМІНІВ}

\author{
Пуш О. М. \\ старший викладач кафедри перекладу та філології \\ ЗВО «Університет Короля Данила» \\ м. Івано-Франківськ, Україна
}

Актуальність дослідження обумовлюється тим, що термінологія, яка обслуговує медицину, є однією з найбагатших термінологічних систем. Вона безперервно поповнюється новими термінами, які потребують 80 
постійного вивчення. Виділяють до 200 галузей медицини, кожна 3 яких має свою окрему систему термінів. Тому медичні терміни привертають особливу увагу лінгвістів та перекладачів.

Мета: описати та проаналізувати основні проблеми перекладу медичних термінів.

Об'єктом дослідження $є$ медична термінологія в медичних текстах різного типу.

\section{Виклад основного матеріалу.}

До складу сучасної медичної термінології входить кілька сотень тисяч слів і стійких словосполучень, які складають термінологічну базу цілого ряду медичних дисциплін. Ця природно сформована система термінів має багатовікову традицію. Характерною особливістю медичної термінології $\epsilon$ використання латинської та грецької мов для утворення термінів. Враховуючи те, що лексичні, граматичні одиниці європейських мов можуть мати певні схожі риси, багато медичних термінів стають міжнародними, зокрема такі слова як in vivo, in vitro, per os, per rectum $(\mathrm{CV})$, є зрозумілими для багатьох. У медицині також зустрічаються і терміни арабського, італійського, німецького, англійського і французького походження [1, с. 111].

Медичну термінологію слід розуміти як систему понять, які позначають стани та процеси, що протікають у людському організмі, хвороби та їхні прояви, методи діагностування, профілактики та лікування захворювань, медичне обладнання, лікарські засоби та ін. Тому терміни можна умовно поділити на ті що представляють різні розділи теоретичної та клінічної медицини, а саме фармакології, медичної техніки i суміжних наук, передусім біології, генетики, біофізики і біохімії та ін.

3 розвитком медицини з'являється велика кількість нових медичних термінів. Все більшої популярності набувають публіцистичні статті медичної тематики, тому багато медичних термінів проникають в загальновживану мову.

Переклад - це складний і багатогранний вид людської діяльності. Основна вимога до перекладу - точність і повнота. Залежно від типу перекладу, наслідки зміни сенсу першоджерела можуть бути різними. Якщо йдеться про переклад медичних текстів, документів, то такими наслідками може стати заподіяння шкоди людському життю.

Перекладач наукової і технічної літератури повинен добре володіти не тільки відповідними мовами і тематикою, а й науковим мисленням, логічними категоріями тієї чи іншої галузі, в тому числі і медицини. 3 цього також випливає можливість виявлення основних конкретних 
закономірностей перекладу наукової і технічної літератури, що забезпечують основну задачу перекладу - ясну і чітку інформацію. Більше того, можна стверджувати, що в деяких випадках переклад наукового i технічного тексту повинен перевершувати оригінал. Це парадоксальне твердження цілком обгрунтовано і випливає як природний наслідок двох вимог, що пред'являються до перекладача наукової та технічної літератури:

а) переклад повинен бути точним, тобто передавати саме те, що міститься в оригіналі - не більше, не менше;

б) в перекладі повинна бути ясність і чіткість незалежно від ступеня ясності оригіналу.

Безперечно медична тематика, мабуть, одна 3 найскладніших. Симптоми хвороби, діагностування, схеми лікування та реабілітаційні заходи, супровідні документи на ліки та медичне обладнання складають область, де неприпустима приблизність формулювань, неточність термінів. Це мова жорстких форм і кліше, точності і аскетизму. Перекладений матеріал повинен містити ретельно вивірену медичну термінологію, щоб не виявитися причиною неточної діагностики, неправильної інтерпретації досягнень науки, i, як наслідок, грубої помилки в професійній діяльності.

Тим не менш, якісний переклад медичних текстів, багатих складною термінологією - це цілком здійсненне завдання, все що для цього необхідно - знання особливостей та класифікації термінів, способів їх утворення і способів перекладу [2, с.166].

Терміносистема медицини інтернаціоналізована, що зумовлюється використанням багатьма мовами греко-латинського фонду як джерела словотвірних формантів. Кількість інтернаціональних термінів у медицині дорівнює приблизно 89\%. У такій ситуації переклад термінів здебільшого зводиться до знаходження відповідних одиниць у мові перекладу чи до утворення складного терміна 3 використанням арсеналу терміноелементів, які існують у мові [3, с.329].

Інша перекладацька проблема медичної термінології - це іiі поповнення термінами епонімами для позначення нових понять (терміни, що утворюються від імені дослідника, що відкрив певну хворобу). Ось чому перекладачеві перш за все слід брати до уваги структуру терміна та його словотворчі моделі, які допоможуть правильно зорієнтуватися в природі терміна та зробити вірний переклад.

Отже, за своєю будовою існують прості терміни, складні, багатокомпонентні, терміни-словосполучення та похідні терміни, що утворилися шляхом афіксації. Прості медичні терміни це окремі 
іменники, які позначають конкретні поняття, що складаються з одного слова ulcer- виразка; складні, утворюються за допомогою декількох окремих слів і можуть містити узгоджене, неузгоджене означення або те й інше одночасно: immunofluorescence method - імунофлюоресцентний метод, dyspersia hepatica печінкова дисперсія; та багатокомпонентні терміни, що мають у своєму складі три і більше слів: saccular aneurysm of aorta - саккулярна аневризма аорти, enphysema pulmonum diffusum дифузна емфізема легень; терміни-словосполучення, що складаються 3 декількох компонентів: cerebellopontodorsal tract- мозжечковопонтодорсальний шлях [4].

Крім відповідальності, уважності, володіння термінологією й розуміння характеру тексту перекладач має знати й про інші особливості медичних текстів. Одна 3 них - наявність у спеціалізованій медичній літературі особливих скорочень і абревіатур. Абревіатурами позначають діагностичні процедури, методи лікування, назви хвороб, найменування лікарських препаратів. Деякі з них відомі повсюдно, наприклад, слова СНІД і УЗИ розшифрує кожний. Але часто зустрічаються й маловідомі вузькоспеціалізовані скорочення - ТБЦ, МДП і безліч інших схожих слів, що виглядають як набір літер. Переклад таких скорочень i абревіатур являє собою додаткову складність.

Також до проблем перекладу відноситься наявність у медичній термінології великої кількості «хибних друзів перекладача», тобто слів, які мають подібну форму, але різне значення [5].

У такому разі термін класичного походження, який існує в одній мові, може створити враження про те, що подібний за формою і з тим же значенням термін існує в усіх мовах, і автори вдаються до його транслітерації, не підозрюючи про наявність інших варіантів:

cellulitis - не «целюліт», а флегмона;

potent pathogen (про бактерію) не «потенційний», а потужний патоген, тобто просто патоген;

symptomatic може означати не тільки симптоматичний, але мати значення $з$ клінічними проявами, наприклад: symptomatic hypertension артеріальна гипертонія з кліничними проявами, а не «симптоматична артеріальна гіпертонія», але symptomatic therapy - симптоматична терапія.

Можливо, серед найбільш серйозних труднощів, з якими повсякчас стикаються перекладачі, $є$ вміння знаходити еквівалентні медичні терміни. Хоча більшість медичних термінів має грецьке і латинське походження, але їхні значення в різних мовах не завжди можуть бути однаковими. 
Висновок. Таким чином переклад текстів медичної тематики можна вважати одним із найскладніших, через те, що медицина $є$ наукою, у якій точність відіграє величезну роль. Від точності розрізу й кількості препарату, що вводиться, може залежати життя й здоров'я людини. Тому медичний переклад не допускає можливості помилок.

При перекладі медичної документації неприпустима приблизність формулювань, неточність термінів. До проблем перекладу текстів медичного спрямування відносяться декілька факторів таких, як: значна кількість синонімів, широке використання абревіатур та скорочень, медичний вокабуляр, що постійно поповнюється та розширюється, наявність «хибних друзів перекладача».

\section{Література:}

1. Світлична С. І., Толок І.О. Латинська мова. Київ: Центр учбової літератури, 2011. $440 \mathrm{c}$.

2. Пєшкова Т. Особливості перекладу німецькомовного тексту медичної літератури. Філологічний дискурс. 2018. №8. С. 166-173.

3. Калашник В.С., Пилипенко М., Корнейко І. Проблеми перекладу медичної термінології . Людина та образ у світі мови : вибрані статті. Харків: ХНУ ім. В.Н. Каразіна, 2011. С. 328 - 333.

4. Карабан В. Переклад англійської наукової і технічної літератури. Вінниця: Нова книга, 2004. 577 с.

5. Дубический В. В. Лексические параллели. Харків: Харьковское лексикограф. общ-во, 1993. 152 с. 